\title{
The Impact of Intangible Assets and R\&D Expenditure on the Market Capitalization and EBITDA of Selected ICT Sector Enterprises in the European Union
}

\author{
Marta Postuła ${ }^{1} \&$ Wojciech Chmielewski ${ }^{2}$ \\ ${ }^{1}$ Center of Entrepreneurship at the Faculty of Management, Warsaw University, Warsaw, Poland \\ ${ }^{2}$ Faculty of Management, Warsaw University, Warsaw, Poland \\ Correspondence: Marta Postuła, Center of Entrepreneurship at the Faculty of Management, Warsaw University, \\ Warsaw, Poland. E-mail: mpostula@wz.uw.edu.pl
}

Received: June 22, 2019

Accepted: July 23, 2019

Online Published: July 29, 2019

doi:10.5539/ijef.v11n8p117

URL: https://doi.org/10.5539/ijef.v11n8p117

\begin{abstract}
In the present paper, using the panel regression model with fixed effects, it was verified whether there is a relationship between intangible assets and $R \& D$ expenses on one side and the EBITDA level and market capitalization of 222 publicly listed companies from the Information and Communication Technology sector. Our research confirmed that in the group of companies from the ICT sector there is a medium of dependence of EBITDA on intangible assets and R\&D expenditure.

At the same time, at the level of the entire ICT sector, no relationship was found between the level of intangible assets and expenditures on research and development on the one hand, and the level of market capitalization of companies on the other. A similar lack of dependence was recorded in the ICT services and ICT manufacturing subsectors.

In addition, there was a high correlation at the level of $74 \%$ between the level of intangible assets and R\&D expenditure on the one hand and the EBITDA level obtained by companies from the ICT manufacturing sub-sector and the lack of such correlation in the ICT services sub-sector.

Our research suggests that, in particular, the financial results of companies in the ICT sector may directly depend on the amount of expenses that companies incur in order to introduce new innovative solutions into their market offer.
\end{abstract}

Keywords: ICT sector, value of enterprise, intangible assets, R\&D expenditures, market capitalization, EBITDA

\section{Introduction}

New Information and Communication Technologies (ICT) have transformed the production process of many existing economic sectors. Thanks to the digital technologies the ICT sector is, to a great degree, responsible for the phenomenon of globalization and the fragmentation of production processes at different stages (the so called global value chains).

The role of companies from the ICT sector in the global economy will grow significantly. This is influenced by many factors, in particular by the rapidly expanding amount of digital data generated by enterprises that can be used for business purposes. Companies offering digital corporate data management services are developing very dynamically, recording a substantial growth across major levels of their operations.

Over the last ten years, the value of entities from this sector has increased significantly. The growing digitization of the global economy will contribute to a further increase in value, but on the other hand it is difficult to determine what kind of restrictions to this trend may occur.

In the case of the European Union ICT sector, its Value Added (VA) amounted to 581 billion euros, it employed 5.8 million people and spent 30 billion euros on business enterprise expenditure on R\&D (BERD). The ICT sector represented $3.9 \%$ of the EU value added, $2.5 \%$ of total employment, $15.7 \%$ of total BERD, and $18.6 \%$ and $20.6 \%$ of the R\&D personnel and researchers in the EU, respectively.

The growing importance of the ICT sector is linked to its better business indicators compared to other sectors of 
the economy. The ICT manufacturing sector is one of the most dynamic sectors in the economy, standing out for its high Research and Development (R\&D) intensity and for a higher productivity than in the economy as a whole. From 1995 to 2015, the EU ICT sector multiplied its VA in real terms by a factor of 3.5, while the total economy did so by 1.4. According to estimates, in 2016 and 2017 the ICT services sector increased its weight in the economy (Mas, Fernández de Guevara, Robledo, \& López-Cobo, 2017).

In the literature, there are no studies analyzing what kind of financial factors influence the value of publicly listed companies from the ICT sector. There are only several studies identifying the factors that affect the price of listed companies investing in ICT solutions. However, it is difficult to find research in the literature on what drives the value of publicly listed companies in the ICT sector.

Given the dynamics in which the ICT sector is developing, research into the impact of selected factors on the value of companies from this sector should be considered relevant for at least several reasons from the research point of view.

The ICT sector companies offer their clients technologically advanced solutions that are used to boost the competitive advantage in the market. The opportunity to provide advanced solutions is related to research and development expenditure incurred by the companies. This may confirm the thesis that the business model of companies in the ICT sector is based on investments in R\&D.

The main goal of the article is to verify two hypotheses:

- whether for companies from the ICT sector covered by the research sample there is a relationship between selected balance sheet values such as intangible assets and $R \& D$ expenditure, and the company capitalization. Although the value of a company is understood in several ways, in the case of companies listed on the public market, the value of a company reflects its capitalization, which is the product of the value and number of shares.

- whether there is a relationship between selected balance sheet values such as intangible assets and R\&D expenditures, and the EBITDA value.

Considering the fact that the business model of companies in the ICT sector is based on launching new technological solutions on the market, it is important to answer the question whether there is a relationship between the level of intangible assets and financial results. For this purpose, the value of EBITDA (earnings before interest, taxes, depreciation and amortization) was chosen, i.e. an enterprise's operating profit before deducting interest on its interest-bearing liabilities (loans, bonds), taxes, amortization of intangible assets and depreciation of property, plant and equipment. The advantage of the EBITDA ratio is that it is based on historical data included in financial statements, which, in accordance with the applicable accounting regulations, are certified as reliable by a statutory auditor. In contrast to forecast figures, the data included in financial statements can be relied on.

\section{Literature Review}

There is no one generally accepted method of measuring the value of an enterprise. In the context of assessing the effectiveness of managing the enterprise value, it is noted that it is possible taking into account two aspects in this area, i.e. factors affecting the value and performance indicators.

The process of identifying the factors that affect the value is an individualized one and works differently in each company. Their usefulness in business management increases when they are grouped according to the criterion of their impact on value (Copeland, Koller, \& Murrin, 1997, p. 98).

According to the view presented by Black, Wright, and Bachman (2008, p. 34) value drivers can be divided into: strategic, financial and operational. The transition from the strategy level to the operational activities passes through the area of financial value drivers, which should be treated as tools for implementating value creation processes in the enterprise. The operational value drivers depend on the business profile of an enterprise.

Enterprises concentrate their activity in the area of intangible assets, because thanks to the knowledge derived from them, they gain a competitive advantage on the market. According to Kaplan and Norton (2001, p. 23), competent use of the intangible assets acquired and held ensures:

- efficient, fast and effective production of high quality products and services tailored to the needs of customers,

- the ability to find new customer groups and maintain good relationships with existing customers, to ensure their loyalty, and to enter new market areas,

- implementation of innovative products and services being a consequence of responding to the expectations of target groups of clients, 
- creation of information technologies, information systems and databases,

- more effective motivation of employees for professional development, improvement of competences, enrichment of processes and improvement of quality, as well as shortening the response time to signals from the environment.

Among the intangible assets used for introducing innovative solutions, the most common is the purchase of knowledge from external sources, software purchase and research and development work.

The primary goal of research and development expenditure is to ensure the company's development and improve its financial results. However, unlike other investments, companies can treat $\mathrm{R} \& \mathrm{D}$ investments as a conscious activity that aims to develop innovative solutions. Bushee (1998, p. 306), recognizes investments in R\&D as the most important element in estimating the company's value in the long-term perspective.

A similar view is presented by Kothari, Laguerre, and Leone (2010, pp. 356-357), according to which the results of investments in R\&D are characterized by greater volatility and are more risky than investments in fixed assets components, but they are also a source of long-term benefits for the enterprise. The effects of R\&D investment may involve improving profitability and increasing the competitiveness of the products and services offered.

Coad and Grassano (2016), based on a broad review of contemporary research, assert that the most important reason for investing in R\&D in enterprises is the expected increase in sales revenues. Enterprises tend to invest a fixed portion of their revenues in $R \& D$ when the amount of operating profits is much lower.

One of the more interesting trends in research concerns the relationship between the source of funding and the intensity of R\&D work. The results of most studies (Bond, Harhoff, \& van Reenen, 2005; Hall, 2002, Pellegrino \& Savona, 2017) indicate that research and development work faces serious barriers to access to external sources of capital, which is explained by the high risk of this type of investment, lack of security and a high level of information asymmetry between capital providers and the research unit.

Research by Sougiannis (1994, p. 65) indicates that one dollar invested in R\&D brings an average increase in profits by two dollars over the next five years and an increase in market value by five dollars. These tests were conducted on a sample of US listed companies in the period covering 1975-1985. There is a research approach which assumes that a company's market value is shaped both by its tangible and intangible circumstances, which are of major importance to its future profitability (Thomadakis, 1977; Lindenberg \& Ross, 1981; Hirschey \& Wichern, 1984).

In one of the market research approaches, a research structure appears which consists in simulating the value of $R \& D$ assets in the balance sheet. The relationship between the value of these assets and the profitability of shares of the companies in question or their market capitalization is analyzed. In this perspective, there are studies by Hirschey and Weygandt (1985) and Lev and Sougiannis (1999) which try to explain the difference between the book value and the market value of listed companies without taking into account the balance sheet assets related to $R \& D$ expenditure.

Similar research regarding the relationship between research and development expenditure and market reaction in the form of abnormal returns is carried out by Liao and Lin (2017). As a result of the conducted research, they found a significant and positive relationship between increasing R\&D outlays and the excess return on shares for companies with high-quality corporate governance.

In the high technology sector, research conducted on a sample of semiconductor companies has shown that R\&D investments are a prerequisite for achieving above-average profitability (Shen, Yan, \& Tzeng, 2017).

Recent years have seen a significant rise in interest in business development in empirical research. Among the factors determining the development of enterprises, three groups are distinguished: structural, macroeconomic and financial.

Among the structural factors, almost every study indicates the age and the size of the enterprise as determinants of growth, the younger being less developed. More recent studies show that smaller enterprises grow faster because they are able to achieve production scale in business with minimal effects (Almus, 2002; Voulgaris, Asteriou, \& Agiomirgianakis, 2003; Honjo \& Harada, 2006; Moreno \& Casillas, 2007). At the same time, smaller companies adapt more flexibly to market conditions, which results from the fact that they are better able to assess the level of risk associated with new investments (Serrasqueiro, Nunes, Leitão, \& Armada, 2010).

Attention is paid to the level of concentration in industry as an important factor positively affecting the development of the company. This is related to their greater activity in the area of concentration, which boosts the exchange of knowledge between companies as observed by Reichstein, Dahl, Ebersberger, and Jensen (2010); 
Bogas and Barbosa (2013), however, argue that in a heterogeneous environment, the presence of diverse needs entails significant development of enterprises with different business profiles in a given area. Productivity of employees influences the overall development of the enterprise (Voulgaris et al., 2003, Navaretti et al., 2014).

In the group of structural factors affecting the development of an enterprise it is possible to distinguish: the industry in which the company operates (Becchetti \& Trovato, 2002; Lopez-Garcia \& Puente, 2012), the legal form of the company (Almus, 2002; Wyrwich, 2010), the region where it operates (Levratto et al., 2010).

In scientific research, another group of factors that have an impact on the company's development are macroeconomic factors.

Most often, foreign investments including export of products and services are indicated (Becchetti \& Trovato, 2002; Hermelo \& Vassolo, 2007). This is related to the fact that foreign expansion is possible with the existence of an appropriate level of company development.

The external environment in which the company operates has a significant impact on the company development, e.g. the banking system or the stock exchange is highly correlated with the growth of the enterprise (Liu \& Hsu, 2006). Similarly, the high rate of economic growth has a positive effect on the expansion of foreign markets (Liu \& Hsu, 2006; Levratto et al., 2010).

Among the financial factors affecting development, the most commonly used growth measures related to finances include the increase in assets, equity, net profit per share and sales (Ardishvili et al., 1998).

Other factors are associated with external financing of the company's operations. Research indicates that access to external financing (Becchetti \& Trovato, 2002, Mateev \& Anastasov, 2010), as well as the use of own financial resources owned by the company improves development opportunities. Government grants and subsidies are treated as having an impact on the company's development (Honjo \& Harada 2006; Wyrwich, 2010).

The existence of a relationship between profit and enterprise development was also noticed, which is due to the fact that in the first place companies use their own resources to expand their business (Hermelo \& Vassolo, 2007; Notta \& Vlachvei, 2009).

The liquidity situation affects the company's development. Liquidity reflected by liquidity ratios is correlated with the development of enterprises as observed by Oliveira and Fortunato (2006) or Giannangeli, Fagiolo, and Molinari (2008). Repayment of a company's liabilities is correlated with the development of the company (Voulgaris et al., 2003).

Ardishvili et al. (1998) and Barkham et al. (1986) believe that sales growth is the best indicator of company growth both in the short and in the long run. The increase in sales, however, does not take into account profitability and may cause a drop in the value of an enterprise if the costs of producing products or financing the company are too high.

Many studies indicate that innovation has a positive impact on the growth of enterprises - enterprises using new technologies are growing faster than others (Liu \& Hsu, 2006; Serrasqueiro et al., 2010; Schimke \& Brenner, 2011). Mitusch and Schimke (2011) indicate innovation as the main factor in the rapid growth of a company. Segarra and Teruel (2011) point to internal research and development investment as a factor that provide growth above average. It should also be noted that the choice of growth measures is subjective and not based on broad analyses (Weinzimmer, Nystrom, \& Freeman, 1998).

The above list shows the multiplicity of research perspectives, which, regardless of the fact that they contribute to expanding the knowledge about company growth drivers, constitute an open catalog. From the point of view of research on the value of a company, it is very important to analyse the company's innovativeness.

\section{Research Method}

Since the essence of the ICT sector is the production of advanced technological products or offering technologically advanced services, there should be a relationship between the level of intangible assets and expenditure on research and development, on the one hand, and a company's market capitalization and the value of EBITDA, on the other.

\subsection{Sample Size}

In the group of the EU companies, the market capitalization of the ICT manufacturing sector is at USD 193 billion in 2017 and in the ICT services sector, at USD 543 billion. The information comes from the Orbis database and includes financial information reported in the annual financial statements between 2008 and 2017 
by selected enterprises of the ICT sector listed on all public markets of 28 European Union countries.

The affiliation of the companies under review to the ICT sector was determined based on the classification of industry sectors NACE Rev. 2 taking into account technological innovation. The classification was created by Eurostat within the framework of the Statistical Classification of Economic Activities in the European Union (Nomenclature statistique des Activités économiques dans la Communauté Européenne, NACE).

According to the NACE Rev. 2, in the entire ICT sector of companies listed on public markets of 28 European Union countries, 222 entities were identified. The ICT sector is divided into two sub-sectors, namely: ICT manufacturing with 77 entities and ICT services with 145 entities.

\subsection{Research Design}

The aim of the study is to determine variables, i.e. intangible assets, research and development expenditure (explaining variables), market capitalization and EBITDA (explanatory variables) in the ICT sector for companies covered by the study as well as the relationship between the above-mentioned variables within companies from the ICT sector subsectors, i.e. ICT manufacturing and ICT services.

For research purposes, a panel regression model with fixed effects has been developed to verify as follows:

- Model I verified how intangible assets and research and development expenditure affect the market capitalization of enterprises.

- Model II examined the relationship between intangible assets as well as research and development expenditure and the EBITDA value obtained by the companies included in the sample.

In the adopted models, the market capitalization of enterprises from the ICT sector and the EBITDA value achieved by these enterprises are explained variables, while the level of intangible assets and expenditure on research and development in the enterprises covered by the study are explanatory variables.

To verify the models, statistics such as $\mathrm{R}^{2}$, the sum of residual squares, statistics $\mathrm{F}$, chi-square and the Hausman test were used. The $\mathrm{F}$ test and the Hausman test confirm that the fixed effects parameters are compatible, so the fixed effects model is a model with better properties.

Considering that the research sample includes objects of the same type (companies above a certain capitalization threshold from one sector) and that it is important in the study to estimate the group effects for these objects, the fixed effects (FE) model is more appropriate according to the literature. The another approach - the 'random effects' (RE) model is considered inappropriate if it could be applied to randomly selected objects from a certain population (small companies, households), for which the estimation of specific group effects is less important because the study focuses on the characteristics of the whole population.

\section{Results of the Research}

Generally speaking, the research has confirmed a medium dependence of EBITDA on intangible assets and R\&D expenditure. Such a dependence seems natural, but it has not been established at a very high level, which also opens up an interesting research perspective in this area.

It is worth noting that the correlation between the explanatory variables and the EBITDA value is quite clearly different in ICT sub-sectors. The ICT manufacturing sub-sector has a correlation of $74 \%$. There may be many reasons, e.g. it may be related to an enterprise delivering better financial results when it sells both computer hardware and services related to its operation. It also seems that the financial result for the ICT manufacturing sector can be modelled, to a greater extent than in the case of ICT services subsector, based on the existing legal provisions. An example could be the possibility to increase sales of the offered products thanks to the provisions allowing customers to lease products from companies in the ICT manufacturing sub-sector. The offer of companies from the ICT services sector may also be leased, but to a much lesser extent.

In the case of the ICT services sub-sector, the correlation of EBITDA with explanatory variables is clearly lower than in the ICT manufacturing sub-sector and amounts to 47\%. It is interesting because the capitalization of companies in the ICT services sub-sector is more than 2.5 times higher than in the ICT manufacturing sub-sector. This would indicate that investors focus more on the potential of the area in which the enterprise operates, and consider it higher for services than for manufacturing. This would require further research, especially that the explanatory variables selected for the analysis presented are not the only ones that contribute to the specificity of the ICT sector. The literature also lists such factors as the level of assets or sales as having a very large impact on a company's value growth.

Regarding the impact of the level of intangible assets and of the level of expenditure on research and 
development on the market capitalization of ICT sector enterprises, this research did not confirm such dependence. Of course, this opens a field for research into which other factors are important enough for investors to determine the decision to invest in the company.

As for company market capitalization, the selection of factors that affect it should concern other variables than intangible assets and expenditure on research and development. The capitalization phenomenon is very interesting not only in the field of economic research. A huge disproportion in capitalization between companies listed on the US and the EU markets (APPLE was the first listed company whose capitalization exceeded, in August 2018, USD 1 trillion while the capitalization of the entire EU ICT sector stands at around USD 780 billion) shows research potential not only in the economic sphere, but also in the field of sociology, marketing or legal solutions.

\subsection{Research Details}

Along with the growth of intangible assets by 1,000 units in the entire ICT sector (ICT manufacturing and ICT services), the value of market capitalization increases on average by 0.6176 units, while with the increase in expenditure on $R \& D$ by 1000 units, the market capitalization rate increases by 0.7413 . The model explains the volatility of market capitalization at $15.08 \%$. This means that the correlation between the level of expenditure on research and development and the level of intangible assets and market capitalization is low.

Based on the results of the study, it can be concluded that the stock exchange valuation of enterprises from the ICT sector on public markets of the European Union shows a $84.92 \%$ correlation with factors other than expenditure on research and development and the level of intangible assets. Stock market investors pay attention to other factors when deciding to invest in a company.

With an increase of 1 unit of expenditure on research and development in the entire ICT sector (ICT manufacturing and ICT services), EBITDA increases by $0.2981 \mathrm{cp}$, while with the increase of intangible assets by 1 unit of EBITDA, the average increases by 0.2913 units. The model explains $51.31 \%$ of the volatility of EBITDA.

This means that the relationship between expenditure on research and development and the growth of intangible assets and the level of EBITDA in the entire sector is on an average level. The results are described in Table 1 below:

Table 1. Results of panel data estimation for EBITDA and market capitalization variables in ICT sector within the years 2008-2017

\begin{tabular}{ccc}
\hline Variable & EBITDA, ICT sector & Market capitalisation, ICT sector \\
\hline Research and development expenses & $.29812387 * * 0074133$ \\
Intangible assets & $.29135628 * * *$ & $.00061763 * * *$ \\
\hline $\mathrm{R}^{2}$ & .51313019 & .15083128 \\
$\mathrm{R}^{2} \_\mathrm{a}$ & .45558373 & .04393238 \\
\hline
\end{tabular}

Source: own elaboration.

Analysis of the relationship between the analyzed variables within the ICT sub-sectors, i.e. ICT manufacturing and ICT services, indicates a greater correlation between variables in the ICT services sub-sector than ICT manufacturing.

With the increase in expenditure by 1 unit for research and development in the ICT manufacturing group, the capitalization ratio increases by 0.0018276 . The model explains $5.16 \%$ of the volatility of market capitalization.

With the increase in expenditure by 1 unit for research and development in the ICT services group, the capitalization ratio is down by 0.000172 . The model explains $20.39 \%$ of the volatility of market capitalization.

The results described above are contained in Table 2:

Table 2. Results of panel data estimation for the market capitalization in the ICT manufacturing and ICT services subsectors within the years 2008-2017

\begin{tabular}{ccc}
\hline Variable & Market capitalisation, ICT manufacturing & Market capitalisation, ICT services \\
\hline Research and development expenses & $.00182764 *$ & -.00017238 \\
Intangible assets & $.00017978^{* * *}$ & $.00084491 * * *$ \\
\hline $\mathrm{R}^{2}$ & .05155461 & .20392616 \\
$\mathrm{R}^{2} \_\mathrm{a}$ & -.06987266 & .10370104 \\
\hline
\end{tabular}

Source: own elaboration. 
An analysis of the correlation between expenditure on research and development, and the level of intangible assets, on the one hand, and the level of EBITDA on the other, looks different for companies in two ICT sub-sectors.

In the case of ICT manufacturing sub-sector, the model explains $73.59 \%$ of the EBITDA volatility in this sub-sector. The correlation is very strong, which proves that the EBITDA result depends on the expenditure on research and development and on the level of intangible assets.

In the case of ICT services subsector, the model explains the volatility of EBITDA in $47.18 \%$. The relationship between expenditure on research and development and the level of intangible assets, and the level of EBITDA is clearly lower in this sub-sector, which would indicate a lower return on R\&D outlays and lower level of intangible assets.

Therefore, it may be justified to conduct further research on the effectiveness of R\&D expenditure within each of the sub-sectors of the ICT sector.

With the increase by 1 unit of expenditure on research and development in group 1, EBITDA in group 1 increases by 0.2242 . The model explains $73.59 \%$ of the volatility of EBITDA.

With the increase by 1 unit of expenditure on research and development in group 2, the EBITDA ratio in group 2 increases by 0.2777 . The model explains $47.18 \%$ of the volatility of EBITDA.

The study reveals a certain research perspective, indicating the average relationship between the level of R\&D expenditure and the EBITDA result. This would justify conducting further research in the area of the impact of $R \& D$ expenditure on other financial indicators, which would give a more precise picture of the actual economic and financial situation of the enterprise, such as financial and market ratios. All data mentioned above are presented in Table 3 below:

Table 3. Results of panel data estimation for EBITDA in ICT manufacturing and ICT services subsectors within the years 2008-2017

\begin{tabular}{ccc}
\hline Variable & EBITDA, ICT manufacturing & EBITDA, ICT services \\
\hline Research and development expenses & .22419817 & .27768833 \\
Intangible assets & $.25387267 * * *$ & $.31047975^{* * *}$ \\
\hline $\mathrm{R}^{2}$ & .73589545 & .47177624 \\
$\mathrm{R}^{2} \mathrm{a}$ & .70450426 & .40897729 \\
\hline
\end{tabular}

Source: own elaboration.

\subsection{Descriptive Statistics of Variables}

The analysis of the descriptive statistics of variables gives some interesting results:

- High values of standard deviation, five times distant from the average, indicate a wide variety. It could mean that the entrepreneurs are not quite homogenous about the importance of intangible assets in the balance sheet of an enterprise. The lowest value in this item is 0 , which may suggest a lack of interest in this area, while the highest value is above USD 100 million, which is already significant as part of the business.

- On average, the value of research and development expenses is negative over USD 110 million. Regarding the spread within the standard deviation, the differences between the minimum and maximum values are very large: it can be interpreted in such a way that the huge in absolute terms the funds that some companies spend on research and development are connected with the connection of revenues with the implementation of new technological solutions in the area in which they specialize.

- The results in the ebitda position are easier to interpret because it concerns the profitability of business operations. Analyzing the difference between the average value of ebitda and the value of standard deviation is about five times, it should be noted that typical enterprises in this sector are able to achieve ebitda five times higher or lower than the average, which is very diversified. However, it should be borne in mind that ebitda is a resultant of the results from core operations, but includes taxation and depreciation, which in a sense explains the minimum deviations from the negative to the positive values for the minimum and maximum values. It is noteworthy, however, that there are companies that in the case of the maximum value are able to record several billion USD EBITDA.

- In the case of the market capitalization variable, the high average value of market capitalization for 
companies in the sector, which amounts to approx. USD 3.5 billion, is noteworthy. It is also worth paying attention to the maximum value of market capitalization, which is over 40 times higher than the average value of market capitalization in the ict sector. Such a significant disproportion may indicate a special approach of investors to some enterprises that take into account other variables in assessing the attractiveness of the company than in the case of companies with an average market capitalization value.

Detailed results are presented in Table 4 below:

Table 4. Descriptive statistics of variables: intangible assets, research and development expenses, EBITDA, market capitalization

\begin{tabular}{lccccc}
\hline Variable & Observations & Mean & Standard Deviation & Min & Max \\
\hline Intangible assets & 2035 & 2138104 & $1.01 \mathrm{e}+07$ & 0 & $1.13 \mathrm{e}+08$ \\
Research and development expenses & 2039 & -110885.4 & 530518.7 & -7203002 & 3718.999 \\
researchde u & 2039 & 110885.4 & 530518.7 & -3718.999 & 7203002 \\
\hline EBITDA & 2039 & 732598 & 3384011 & -1307525 & $3.71 \mathrm{e}+07$ \\
Market capitalization & 1907 & 3529.18 & 12469.74 & 0 & 146492.5 \\
\hline
\end{tabular}

Source: own elaboration.

\subsection{Percentiles'Analysis of the Variables}

Some additional remarks come form the percentiles' analysis of all four variables.

In case of the intangible fixed assests:

- $25 \%$ of companies do not achieve a higher level of intangible assets than 0 .

- $50 \%$ of companies not more than USD 38330050.

- A strong right-sided asymmetry shows that there are a lot of companies with a very low level of intagible assets, but a few companies with a high level of intagible assets increase their average.

The results are shown in Table 5:

Table 5. Percentiles results on intangible fixed assets in ICT sector companies within the years 2008-2017

\begin{tabular}{ccc}
\hline & Intangible fixed assets & \\
\hline Companies' percentage & Percentiles & Smallest \\
\hline $1 \%$ & 95.07963 & 0 \\
$5 \%$ & 1669.797 & 0 \\
$10 \%$ & 3019.963 & 0 \\
$25 \%$ & 8489.277 & Largest \\
$50 \%$ & 38330.05 & $9.53 \mathrm{e}+07$ \\
& & $1.07 \mathrm{e}+08$ \\
$75 \%$ & 201509 & $1.10 \mathrm{e}+08$ \\
$90 \%$ & 1731602 & $1.13 \mathrm{e}+08$ \\
\hline
\end{tabular}

Source: own elaboration.

Percentiles analysis cocerning research \& development expenses shows that:

- As many as 75\% of companies record a higher loss in research and development than USD -1 130869

- 50\% of companies achieve a result higher than USD 6597618

- There are very few companies that showed a positive value in the research $\&$ development expenses position, and positive results are shown at low levels, which reduces the average in this area.

The results are presented in Table 6: 
Table 6. Percentiles results on research and development expenses in ICT sector within the years 2008-2017

\begin{tabular}{ccc}
\hline & Research and development expenses & \\
\hline Companies' percentage & Percentiles & Smallest \\
\hline $1 \%$ & -2335036 & -7203002 \\
$5 \%$ & -426074.8 & -6627006 \\
$10 \%$ & -123746.3 & -6389278 \\
$25 \%$ & -34031.45 & -5895757 \\
$50 \%$ & -6597.618 & \\
& & Largest \\
$75 \%$ & -1130.869 & 146.1846 \\
$90 \%$ & 0 & 541.9863 \\
$95 \%$ & 0 & 1108.296 \\
$99 \%$ & 0 & 3718.999 \\
\hline
\end{tabular}

Source: own elaboration.

The percentiles analysis on EBITDA presents the results as follow:

- only $10 \%$ of companies achieve a result lower than -450513 USD

- $\quad 50 \%$ of companies do not exceed the level of USD 14319200

- $\quad$ over $1 \%$ of enterprises achieve a very high result above USD 203000000 EBITDA

- there are few companies in the sector that recorded negative EBITDA

The results are shown in Table 7 below:

Table 7. Percentiles results on EBITDA in ICT sector within the years 2008-2017

\begin{tabular}{ccc}
\hline & \multicolumn{2}{c}{ EBITDA } \\
\hline Companies' percentage & Percentiles & Smallest \\
\hline $1 \%$ & -27134.38 & -1307525 \\
$5 \%$ & -4091 & -473793.5 \\
$10 \%$ & -450.513 & -386817.7 \\
$25 \%$ & 3571.026 & -239949.5 \\
$50 \%$ & 14319.2 & \\
& & Largest \\
$75 \%$ & 90098.63 & $3.17 \mathrm{e}+07$ \\
$90 \%$ & 711045.4 & $3.41 \mathrm{e}+07$ \\
$95 \%$ & 2016346 & $3.58 \mathrm{e}+07$ \\
$99 \%$ & $2.03 \mathrm{e}+07$ & $3.71 \mathrm{e}+07$ \\
\hline
\end{tabular}

Source: own elaboration.

As regards the market capitalization main results show that:

- $\quad$ only $1 \%$ of companies achieve the market capitalization value less than USD 1614505

- $25 \%$ of companies achieve the value of market capitalization higher than USD 9389101300

- $\quad$ there are few companies with low capitalization in the sector and relatively many companies (25\%) with very high market capitalization, which increases the average.

All percentiles' results on the market capitalization are presented in Table 8 below:

Table 8. Percentiles results on market capitalisation in ICT sector within the years 2008-2017

\begin{tabular}{ccc}
\hline & Market capitalization & Smallest \\
\hline Companies'percentage & Percentiles & 0 \\
$1 \%$ & 1.614505 & 0 \\
$5 \%$ & 9.424151 & 0 \\
$10 \%$ & 18.01883 & 0 \\
$25 \%$ & 43.29957 & \\
$50 \%$ & 156.0414 & \\
\hline
\end{tabular}




\begin{tabular}{ccc}
\hline & & Largest \\
$75 \%$ & 938.9013 & 132307 \\
$90 \%$ & 6449.075 & 136861.5 \\
$95 \%$ & 19968.83 & 138036.9 \\
$99 \%$ & 68985.58 & 146492.5 \\
\hline
\end{tabular}

Source: own elaboration.

\section{Summary}

The results of the research presented in the article show the legitimacy of searching for dependencies between various variables affecting the situation of companies from the ICT sector. Some findings, such as the relationship between the amount of R\&D expenditure incurred by companies in the sector and the EBITDA level, determine the direction of further research and the search for dependencies between other variables such as the level of sales, level of assets and the general economic and financial situation of enterprises.

Given that the ICT sector's share of the economy will most likely continue to grow dynamically, it is justified to conduct cross-sectional research on factors that affect the development of this sector. The results obtained, identifying factors having a positive and negative impact on the development of the ICT sector, can be used as guidelines on the solutions to be adopted to ensure a satisfactory pace of sector development. Considering that the development of the ICT sector is linked to the key areas of public policy regarding innovation, employment or education, it is necessary to construct appropriate tools for growth in this area.

The direction of research may be important not only from the point of view of business development, but also from the perspective of the most important countries such as the USA, China or India, or organizations like the European Union. Although the US is still the leading country in the world, the available data point to the growing role of China and India when it comes to $R \& D$ expenditure. The available studies reveal that China is recording increasingly better results in sectors with higher value added activities - such as those within the ICT producing sector - as well as investing an increasing amount of resources in R\&D.

In the case of the European Union, the development potential of the ICT sector is recognized as its very important role is stressed in key documents regarding the need for digital transformation in the economies of member countries. This is reflected at the EU policy level, where the Digital Agenda for Europe in 2010, with the objective of maximising the social and economic potential of ICT, was identified as one of the seven pillars of the Europe 2020 Strategy for growth. In addition, the achievement of a Digital Single Market (DSM) has been one of the 10 political priorities of the Commission since 2015. It should be noted that although the European Union takes measures to develop the ICT sector, they are insufficient in the context of the pace of changes in the global dimension.

\section{References}

Almus, M. (2002). What characterizes a fast growing firm? Applied Economics, 34(12), 1497-1508. https://doi.org/10.1080/00036840110105010

Barkham, R., Gudgin, G., Hurt, M., \& Hanvey, E. (1986). Determinants of Small Business Growth: An Inter-Regional Study in the United Kingdom. Psychology Press, 12. https://doi.org/10.4324/9780203059777

Becchetti, L., \& Giovanni, T. (2002). The determinants of growth for small and medium sized firms. The role of the availability of external finance. Small Business Economics, 19, 291-306. https://doi.org/10.1023/A:1019678429111

Bogas, P., \& Barbosa, N. (2013). High-Growth Firms: What is the Impact of Region-Specific Characteristics? NIPE Working Papers, 19. https://doi.org/10.1007/978-3-319-12871-9_15

Bond, S., Harhoff, D., \& van Reenen, J. (2005). Investment, R\&D and Financial Constraints in Britain and Germany. Annales d'Économie et de Statistique, 79/80, 433-460. https://doi.org/10.2307/20777584

Bushee, B. (1998). The Influence of Institutional Investors on Myopic R\&D Investment Behavior. The Accounting Review, 73(3), 305-333.

Coad, A., \& Grassano, N. (2016). Who's Doing Who? Growth of Sales, Employment, Assets, Profits and R\&D Entangled in a Curious Five-Way Love Triangle. IPTS Working Papers on Corporate R\&D and Innovation, 03.

Giannangeli, S., Fagiolo, G., \& Molinari, M. (2008). Financial Structure and Corporate Growth: Evidence from 
Italian Panel Data. LEM Working Paper Series, 17, 1-29. https://doi.org/10.1111/ecno.12059

Hermelo, F., \& Vassolo, R. (2007). The determinants of firm's growth: an empirical examination. Revista Abante, $10(1), 3-20$.

Hirschey, M., \& Weygandt, J. (1985). Amortization Policy for Advertising and Research and Development Expenditures. Journal of Accounting Research, 23(1), 326-335. https://doi.org/10.2307/2490921

Honjo, Y., \& Harada, N. (2006). SME Policy, Financial Structure and Firm Growth: Evidence from Japan. Small Business Economics, 27, 289-300. https://doi.org/10.1007/s11187-005-6703-0

Kothari, S. P., Laguerre, T., \& Leone, A. (2002). Capitalization versus expensing: Evidence on the uncertainty of future earnings from capital expenditures versus R\&D outlays. Review of Accounting Studies, 7(4), 355-382. https://doi.org/10.1023/A:1020764227390

Lev, B., \& Sougiannis, T. (1999). Penetrating the book-to-market black box: The R\&D effect. Journal of Business Finance and Accounting, 26(3-4), 419-449. https://doi.org/10.1111/1468-5957.00262

Levratto, N., Tessier, L., \& Zouikri, M. (2010). The determinants of growth for SMES. A longitudinal study from French manufacturing firms. EconomiX-CNRS-University of Paris Ouest Working Papers, 28, 1-30. https://doi.org/10.2139/ssrn.1780466

Liao, T. L., \& Lin, W. Ch. (2017). Corporate Governance, Product Market Competition, and the Wealth Effect of R\&D Spending Changes. Financial Management, 46(3), 717-742. https://doi.org/10.1111/fima.12161

Lindenberg, E., \& Ross, S. (1981). Tobin's q Ratio and Industrial Organization. The Journal of Business, 54(1), 1-32. https://doi.org/10.1086/296120

Liu, W. Ch., \& Hsu, Ch. M. (2006). Financial structure, corporate finance and growth of Taiwan's manufacturing firms. Review of Pacific Basin Financial Markets and Policies, 9(1), 67-95. https://doi.org/10.1142/S0219091506000653

Lopez-Garcia, P., \& Puente, S. (2012). What makes a high-growth firm? A dynamic probit analysis using Spanish firm level data. Small Business Economics, 39, 1029-1041. https://doi.org/10.1007/s11187-011-9321-z

Mas, M., Fernández de Guevara, J., Robledo, J. C., \& López-Cobo, M. (2017). The 2017 PREDICT Key Facts Report. An Analysis of ICT R\&D in the EU and Beyond. Retrieved from https://ec.europa.eu/jrc/sites/jrcsh/files/2017_predict_key_facts_report.pdf

Mateev, M., \& Anastasov, Y. (2010). Determinants of small and medium sized fast growing enterprises in Central and Eastern Europe: A panel data analysis. Financial Theory and Practise, 34(3), 269-295.

Moreno, A., \& Casillas, J. (2007). High-growth SMEs versus non-highgrowth SMEs: A discriminant analysis. Enterpreneurship \& Regional Development, 19, 69-88. https://doi.org/10.1080/08985620601002162

Navaretti, G., Castellani, D., \& Pieri, F. (2014). Age and firm growth: Evidence from three European countries. Small Business Economics, 43, 823-837. https://doi.org/10.1007/s11187-014-9564-6

Notta, O., \& Vlachvei, A. (2009). Rapid-growth firms in Greece: An empirical investigation. Proceedings of International Conference on Applied Economics (pp. 527-534). TEI of Western Macedonia Press.

Oliveira, B., \& Fortunato, A. (2006). Firm growth and liquidity constraints: A dynamic analysis. Small Business Economics, 27, 139-156. https://doi.org/10.1007/s11187-006-0006-y

Reichstein, T., Dahl, M., S., Ebersberger, B., \& Jensen, M., B. (2010). The devil dwells in the tails: A quantile regression approach to firm growth. Journal of Evolutionary Economics, 20(2), $219-231$. https://doi.org/10.1007/s00191-009-0152-X

Schimke, A., \& Thomas, B. (2011). Long-run factors of firm growth - A study of German firms. KIT Working Paper Series in Economics, 21, 2-20. http://dx.doi.org/10.5445/IR/1000022809

Schreyer, P. P. (2000). High-growth organizations and employment. Working Papers, OECD.

Segarra, A., \& Teruel, M. (2011). High Growth firms and Innovation: an empirical analysis for Spanish firms. CREIP, Working Papers 32 Reus. https://doi.org/10.1596/1813-9450-5906

Serrasqueiro, Z., Nunes, P., Leitão, J., \& Armada, M. (2010). Are there non-linearities between SME growth and their determinants? A quantile approach. Industrial and Corporate Change, 19(4), 1071-1108. https://doi.org/10.1093/icc/dtp053 
Shen, K. Y., Yan, M. R., \& Tzeng, G. H. (2017). Exploring R\&D Influences on Financial Performance for Business Sustainability Considering Dual Profitability Objectives. Sustainability, 9, 1-21. https://doi.org/10.3390/su9111964

Sougiannis, T. (1994). The Accounting Based Valuation of Corporate R\&D. The Accounting Review, 69(1), 44-68.

Voulgaris, F., Asteriou, D., \& Agiomirgianakis, G. (2003). The determinants of small firms growth in the Greek manufacturing sector. Journal of Economic Integration, 18(4), 817-836. https://doi.org/10.11130/jei.2003.18.4.817

Weinzimmer, L., Nystrom, P., \& Freeman, S. (1998). Measuring organizational growth: Issues, consequences and guidelines. Journal of Management, 24(2), 235-262. https://doi.org/10.1016/S0149-2063(99)80061-0

\section{Copyrights}

Copyright for this article is retained by the author(s), with first publication rights granted to the journal.

This is an open-access article distributed under the terms and conditions of the Creative Commons Attribution license (http://creativecommons.org/licenses/by/4.0/). 